\title{
ANALISIS KOMPOSISI UNSUR, DENSITAS, MAKROSTRUKTUR, DAN FASA PADUAN U-6Zr-xNb PASCA UJI KOROSI
}

\author{
Masrukan', Deni Mustika1, Deninta Andara Perdana², Jumaeri² \\ ${ }^{1}$ Pusat Teknologi Bahan Bakar Nuklir - BATAN \\ Kawasan PUSPIPTEK Serpong Gd 20, Tangerang Selatan, 15314 \\ 2Jurusan Kimia, Fakultas Matematika dan IImu Pengetahuan Alam, Universitas Negeri Semarang \\ Gedung D6 Lantai 2, Kampus Sekaran, Gunungpati, Semarang, 50229 \\ e-mail: masrukan2006@yahoo.com
}

(Naskah diterima: 20-9-2020, Naskah direvisi: 14-10-2020, Naskah disetujui: 27-10-2020)

\begin{abstract}
ABSTRAK
ANALISIS KOMPOSISI UNSUR, DENSITAS, MAKROSTRUKTUR, DAN FASA PADUAN U-6Zr-xNb PASCA UJI KOROSI. Penelitian mengenai komposisi unsur, densitas, makrostruktur, dan fasa paduan U-6Zr-xNb pasca uji korosi telah dilakukan. Analisis komposisi paduan dilakukan sebelum uji korosi yang meliputi uji kadar uranium dengan titrasi potensiometri, uji kadar pengotor dengan Atomic Absorption Spectroscopy (AAS) serta uji kadar $\mathrm{Zr}$ dan $\mathrm{Nb}$ dengan $X$-Ray Fluorescence (XRF). Analisis komposisi paduan bertujuan untuk memastikan bahwa bahan bakar U-6Zr-xNb memenuhi syarat kualitas bahan bakar nuklir. Uji densitas dilakukan untuk menjadi salah satu parameter dalam menghitung laju korosi, sedangkan pengamatan makrostruktur dan fasa paduan dilakukan untuk mengetahui kerusakan atau produk korosi serta lapisan/fasa yang terbentuk setelah terjadi korosi. Hasil uji komposisi paduan U-6Zr-xNb dengan XRF maupun titrasi potensiometri menunjukkan bahwa kadar uranium sudah mendekati kadar yang syaratkan, sedangkan untuk uji pengotor dengan AAS menunjukkan adanya kadar pengotor melebihi yang disyaratkan untuk bahan bakar nuklir antara lain $\mathrm{Al}$, Fe dan Si. Berdasarkan hasil tersebut, bahan bakar U-6Zr-xNb masih memenuhi persyaratan. Dilihat dari sifat neutroniknya, unsur Al, Fe dan $\mathrm{Si}$ memiliki tampang serapan neutron yang rendah. Hasil uji densitas sampel U-6Zr, U-6Zr-1Nb, U-6Zr-4Nb, dan U-6Zr-7Nb masing-masing sebesar 16,9798 g/mL, 16,6115 g/mL, 15,594 g/mL, dan $15,3564 \mathrm{~g} / \mathrm{mL}$. Pengamatan makrostruktur paduan pasca korosi menunjukkan adanya bercak hitam yang merupakan hasil oksidasi U (IV) menjadi U (VI). Paduan U-6Zr-xNb mengalami korosi paling besar pada media air bebas mineral. Kerusakan pada permukaan paduan semakin menurun seiring bertambahnya presentase berat $\mathrm{Nb}$ dalam paduan. Hasil karakterisasi paduan pasca korosi menggunakan XRD menunjukkan bahwa sampel $\mathrm{U}-6 \mathrm{Zr}$ dan $\mathrm{U}-6 \mathrm{Zr}-1 \mathrm{Nb}$ terbentuk fasa $\alpha$, sedangkan untuk sampel U-6Zr-4Nb dan U-6Zr-7Nb terbentuk fasa $\mathrm{Y}$. Lapisan oksida protektif $\mathrm{Nb}_{2} \mathrm{O}_{5}$ yang terbentuk sangat kecil, sehingga tidak terdeteksi oleh XRD.
\end{abstract}

Kata kunci: Paduan UZrNb, komposisi, pengotor, korosi, densitas, makrostruktur, pembentukan fasa. 


\section{ABSTRACT}

ANALYSIS OF ELEMENTAL COMPOSITION, DENSITY, MACROSTRUCTURE, AND PHASE FORMATION OF U-6Zr-XNb ALLOY POST CORROSION TEST. Research on the elemental composition, density, macrostructure, and phase formation of $U-6 Z r-x N b$ alloy have been done after corrosion test. The alloy composition analysis had been done before the corrosion test which included uranium content analysis by potentiometric titration, impurity analysis with Atomic Absorption Spectroscopy (AAS), and $U, Z r$ and $\mathrm{Nb}$ content analysis with $X$-Ray Fluorescence (XRF). The alloy composition analysis was aimed to ensure that $U-6 Z r-x N b$ fuel meets the quality requirements of nuclear fuel specifications. The density, macrostructure and phase test were done after the corrosion test. The density test is required as one of the parameters in calculating the corrosion rate, and the microstructure and alloy phase observations are required to determine the damage or corrosion products and the layers/phases formed after the occurance of corrosion. The results of the U-6Zr-XNb alloy composition analysis with XRF and potentiometric titration show that the uranium content is close to the expected level, whereas the impurity test with AAS shows high levels of impurities including $\mathrm{Al}$, Fe and Si. Based on these results, U-6Zr-xNb fuel meets the requirements because the elements of $\mathrm{Al}, \mathrm{Fe}$ and Si have low neutron absorption cross-section. The sample density test results of U-6Zr, U-6Zr-1Nb, U-6Zr-4Nb, and U-6Zr-7Nb were 16.9798 $\mathrm{g} / \mathrm{mL}, 16.6115 \mathrm{~g} / \mathrm{mL}, 15.594 \mathrm{~g} / \mathrm{mL}$, and $15.3564 \mathrm{~g} / \mathrm{mL}$ respectively. Macrostructure observation of the post-corrosion alloy shows black spots which are the result of oxidation of $U$ (IV) to $U(V I)$. The $U-6 Z r-x N b$ alloy experiences the greatest corrosion in mineral-free water media. The damage to the alloy surface decreases as the weight percentage of $\mathrm{Nb}$ in the alloy increases. The results of post-corrosion alloy characterization using XRD show that the U-6Zr and U-6Zr-1Nb samples formed an a phase, while the U-6Zr-4Nb and U-6Zr-7Nb samples formed $y$ phase. The protective $\mathrm{Nb}_{2} \mathrm{O}_{5}$ oxide layer formed, however, is minute and unlikely to be detected by XRD.

Keywords: UZrNb alloy, elemental composition, impurities, corrosion, density, macrostructure, phase formation. 


\section{PENDAHULUAN}

Bahan bakar nuklir adalah bahan yang dapat menghasilkan energi melalui proses fisi, dan merupakan komponen pokok pada reaktor nuklir. Faktor kunci untuk pengembangan bahan bakar nuklir adalah sifatnya yang aman dan ekonomis [1]. Pengembangan bahan bakar di Pusat Teknologi Bahan Bakar Nuklir (PTBBN), BATAN ditujukan untuk mendapatkan bahan bakar yang mempunyai densitas tinggi. Hingga saat ini, reaktor riset G. A. Siwabessy menggunakan bahan bakar uranium silisida $\left(\mathrm{U}_{3} \mathrm{Si}_{2} / \mathrm{Al}\right)$. Bahan bakar $\mathrm{U}_{3} \mathrm{Si}_{2} / \mathrm{Al}$ tersebut memiliki kekurangan, yaitu sulitnya memisahkan limbah Si dari fabrikasi bahan bakar dan keterbatasan densitas yang dapat dicapai saat difabrikasi. Densitas bahan bakar $\mathrm{U}_{3} \mathrm{Si}_{2} / \mathrm{Al}$ yang dapat dicapai pada saat proses fabrikasi adalah sebesar $4,8 \mathrm{gU} / \mathrm{cm}^{3}$ [2] . Salah satu upaya untuk mengatasi hal tersebut adalah dengan membuat inovasi bahan bakar baru [3]. Untuk itu, diupayakan mencari bahan bakar baru yang mempunyai densitas tinggi dengan salah satunya adalah bahan bakar berbasis uranium zirconium (U-Zr) selain uranium molybdenum (U-Mo).

Bahan bakar paduan uranium dengan fasa $\mathrm{Y}$ merupakan kandidat yang menjanjikan untuk dijadikan bahan bakar LEU karena stabilitasnya lebih baik terhadap iradiasi serta lebih tahan terhadap kondisi swelling. Akan tetapi uranium memiliki sifat fisik dasar berupa fasa $\alpha$, yang hanya stabil pada temperatur ruang atau di bawahnya. Fasa $\mathrm{Y}-\mathrm{U}$ dapat dipertahankan hingga temperatur kamar dengan cara memadukan uranium dengan unsur logam lain seperti zirkonium, niobium, molibdenum, platinum dan lain-lain [4]. Dalam proses fabrikasi bahan bakar nuklir, terdapat proses konversi bahan bakar dari ingot menjadi serbuk, dimana teknik yang umum digunakan untuk membuat serbuk adalah hydride-dehydride (HD). Teknik hydride-dehydride digunakan untuk bahan yang ulet untuk dibuat serbuk dengan cara dimilling/dihancurkan. Yang perlu diperhatian dalam proses hydridedehydride adalah pembentukan $\mathrm{UH}_{3}$ pada proses hydriding-dehydriding yang dapat menghasilkan produk korosi yang bersifat piroforik sehingga menjadi salah satu masalah dalam hal keselamatan operasionalnya [5].

Paduan uranium untuk dapat digunakan sebagai bahan bakar nuklir selain harus mempunyai kemurnian dan densitas yang tinggi juga dituntuk mempunyai sifat rorosi yang cukup baik. Beberapa teknik telah dilakukan untuk meningkatkan performa bahan bakar nuklir terhadap korosi, termasuk memadukan antar logam, pelapisan permukaan dan implan ion. Beberapa logam (seperti $\mathrm{Ti}, \mathrm{Nb}, \mathrm{Zr}$, dan $\mathrm{Ru}$ ) telah dipadukan dengan uranium untuk meningkatkan resistensi terhadap korosi [6]. Dalam penelitian ini, logam $\mathrm{Nb}$ akan dipaduka dengan U-6Zr untuk meningkatkan ketahanan korosinya, selain logam $\mathrm{Nb}$ memiliki penampang lintang serapan neutron yang rendah, memiliki kompatibilitas yang baik dengan logam cair alkali, sifat mekanik suhu tinggi, dan dapat difabrikasi dengan baik, sehingga $\mathrm{Nb}$ cocok untuk dikembangkan dalam bidang nuklir [7]. Selain itu, paduan uranium-zirkonium-Niobium (U-Zr-Nb) dianggap sebagai salah satu bahan bakar nuklir yang menarik untuk reaktor riset, karena memiliki sifat yang menguntungkan seperti densitas dan konduktivitas termalnya yang lebih tinggi, kemudahannya saat difabrikasi, serta kompatibilitasnya yang baik dengan kelongsong bahan bakar [8]. Presentase niobium yang umumnya dapat dipadukan dengan uranium berkisar antara $2 \%$ sampai dengan $7 \%$ berat paduan [9], sehingga pada penelitian ini akan menggunakan variasi berat niobium sebesar $0 \%, 1 \%, 4 \%$, dan $7 \%$.

\section{METODOLOGI}

Paduan U-6Z-xrNb hasil pemaduan logam $\mathrm{U}, \mathrm{Zr}$ dan $\mathrm{Nb}$ dipotong-potong untuk dilakukan beberapa pengujian diantaranya uji korosi, komposisi kimia, densitas, fasa dan 
makrostruktur. Pengujian korosi dilakukan dalam media yang berbeda-beda yaitu media asam media larutan $\mathrm{HNO}_{3}$ dengan $\mathrm{pH} 1,30$; media air bebas mineral dengan $\mathrm{pH} 8,28$; dan dalam larutan basa $\mathrm{NaOH}$ dengan $\mathrm{pH}$ 10,96 .

\section{a. Analisis Kadar Uranium dengan Titrasi Potensiometri}

Sebelum dilakukan pengujan kadar $U$ dengan menggunakan titrasi potensiometri, potongan $\pm 0,5 \mathrm{~g}$ paduan $\mathrm{U}-6 \mathrm{Zr}-\mathrm{xNb}$ dilarutkan dalam $\mathrm{HNO}_{3}$ pekat : $\mathrm{HF}$ pekat = 2500 : 1 dan ditepatkan hingga memiliki konsentrasi $10 \mathrm{~g} / \mathrm{L}$. Larutan yang terbentuk direduksi menjadi U (IV) dengan ferro sulfat dengan bantuan katalis Mo (IV), dilanjutkan proses titrasi menggunakan titroprocessor (Metler Toledo T90) dengan kalium bikromat dan katalis vanadil sulfat sebagai agen oksidator $\mathrm{U}$ (IV) menjadi $\mathrm{U}(\mathrm{VI})$. Analisis Kadar $\mathrm{U}, \mathrm{Zr}$ dan $\mathrm{Nb}$ dengan $X$-Ray Fluorescence (XRF)

Sampel dipotong hingga mempunyai sisi rata. Sisi rata dari sampel kemudian dihaluskan dan diletakkan dalam chamber dengan menghadap ke sumber sinar $X$ dan detektor. Pada penelitian ini, metode pengukuran yang digunakan adalah Uni Quant, dalam media udara, waktu selama 60 detik/sampel, dan tegangan kerja 4-40 kV. Hasil pengujian kemudian dianalisis.

\section{b. Analisis Kadar Pengotor dengan Atomic Absorption Spectroscopy}

Sebagian sampel U-6Zr-xNb yang telah dipotong dengan berat $\pm 0,5 \mathrm{~g}$ dilarutkan menggunakan $\mathrm{HF}$ pekat : $\mathrm{HNO}_{3}$ pekat dalam perbandingan $3: 7$ dengan microwave digester (Milestone Ethos Easy) pada temperatur $240^{\circ} \mathrm{C}$ selama 15 menit. Hasil larutan diekstrak menggunakan TBP : Heksana $=7: 3$ untuk mengikat uranium dalam fasa nonpolar. Fasa polar dan nonpolar kemudian dipisahkan dalam corong pisah. Fasa polar yang didapatkan kemudian diencerkan dan dianalisis menggunakan AAS.

\section{c. Uji Densitas U-6Zr-xNb dengan Autopycnometer}

Pengujian densitas dilakukan dengan metode adisi volume karena sampel berukuran mikroskopis. Spheremicromerities ditimbang menggunakan neraca analitik, kemudian diukur volumenya dengan Autopycnometer (Ultrapyc 1200e). Langkah selanjutnya, sampel ditimbang bersama spheremicromerities dalam satu wadah, dan diukur volumenya lagi. Hasil pengukuran massa dan volume total selanjutnya dikurangi dengan massa dan volume spheremicromerities, sehingga diperoleh data massa dan volume sampel, sehingga nilai densitas masing-masing sampel dapat diketahui.

\section{d. Pengamatan Makrostruktur Paduan U-6Zr-xNb Pasca Uji Korosi}

Sampel U-6Zr-xNb yang telah diuji korosi diamati menggunakan mikroskop optik dengan perbesaran 50x tanpa perlakuan apapun. Adanya bercak hitam di permukaan sampel merupakan pertanda terjadi korosi di permukaan paduan.

\section{e. Analisis Pembentukan Fasa dengan $X$-Ray Diffraction (XRD)}

Sampel U-6Zr-xNb pasca uji korosi masing-masing diuji menggunakan XRD (PANalytical) dengan pengamatan $2 \theta$ dari $30^{\circ}$ hhingga $80^{\circ}$. Pola difraksi yang terbentuk kemudian dianalisis menggunakan software HighScore Plus, sehingga diperoleh fasa yang terbentuk pada paduan.

\section{HASIL DAN PEMBAHASAN}

\section{a. Hasil Analisis Kadar Uranium}

Hasil anallisis kadar $U$ di dalam paduan $\mathrm{U}-6 \mathrm{Zr}-\mathrm{xNb}$ yang dianalisis dengan menggunakan titroprosessor tertera pada Tabel 1. Dalam Tabel 1 terlihat bahwa konsentrasi uranium yang diuji mendekati konsentrasi yang direncanakan. Kadar uranium pada paduan U-6Zr, U-6Zr-1 $\mathrm{Nb}$, U-6Zr-4Nb, dan U-6Zr-7Nb masing-masing memiliki standar deviasi relatif sebesar 
0,0866\%; 1,0140\%; 0,7593\%; dan 1,0536\%. Nilai standar deviasi relatif tersebut di bawah $5 \%$ sehingga hasill analisis dianggap akurat. Dari pengukuran ini, dapat kita ketahui kadar uranium setelah dipadukan dengan logam lain secara lebih teliti mendekati kadar uranium yang diharapkan pada masingmasing paduan yang dibuat.

Tabel 1. Hasil analisis kadar uranium pada paduan U-6Zr-xNb

\begin{tabular}{ccccc}
\hline No. & Sampel & $\begin{array}{c}\text { Konsentrasi uranium yang } \\
\text { direncanakan (\%) }\end{array}$ & $\begin{array}{c}\text { Konsentrasi uranium terukur } \\
\text { rata-rata (\%) }\end{array}$ & $\begin{array}{c}\text { Selisih } \\
(\%)\end{array}$ \\
\hline 1 & $\mathrm{U}-6 \mathrm{Zr}$ & $94 \%$ & 95,13 & 1,13 \\
2 & $\mathrm{U}-6 \mathrm{Zr}-1 \mathrm{Nb}$ & $93 \%$ & 93,02 & 0,02 \\
3 & $\mathrm{U}-6 \mathrm{Zr}-4 \mathrm{Nb}$ & $90 \%$ & 89,26 & 0,74 \\
4 & $\mathrm{U}-6 \mathrm{Zr}-7 \mathrm{Nb}$ & $87 \%$ & 85,85 & 2,85 \\
\hline
\end{tabular}

\section{b. Analisis Kadar $\mathrm{U}, \mathrm{Zr}$ dan $\mathrm{Nb}$ dengan} XRF

Uji komposisi kimia dengan menggunakan $X$-Ray Fluorescence (XRF) digunakan untuk mengukur kadar $\mathrm{U}, \mathrm{Zr}$ dan $\mathrm{Nb}$, dimana unsur-unsur logam tersebut memiliki presentase yang cukup tinggi sehingga lebih mudah dan cepat dalam proses analisis tanpa merusak sampel. Hasil uji kadar $\mathrm{U}, \mathrm{Zr}$ dan $\mathrm{Nb}$ tertera pada Tabel 2.

Tabel 2 menunjukkan bahwa presentase masing-masing logam setelah dipadukan berbeda dengan yang direncanakan. Hal ini diebabkan selain karena adanya proses pemaduan perbedaan hasil uji dengan hasil yang direncanakan juga dapat disebabkan oleh cara kerja XRF yang mengukur pada sisi tertentu saja sehingga antara sisi satu dan sisi lainnya memberikan hasil berbeda karena perbedaan distribusi logam pemadu. Terlihat pula bahwa pada uji komposisi kimia menggunakan XRF, selisih konsentrasi logam yang direncanakan dan yang terukur cukup kecil $(<5 \%)$ sehingga dapat dikatakan bahwa hasil uji masih akurat.

Tabel 2. Data Hasil Analisis Komposisi Kimia dengan XRF

\begin{tabular}{|c|c|c|c|c|c|}
\hline No. & Sampel & Unsur & $\begin{array}{l}\text { Konsentrasi yang } \\
\text { direncanakan (\%) }\end{array}$ & $\begin{array}{l}\text { Konsentrasi } \\
\text { Terukur (\%) }\end{array}$ & Selisih (\%) \\
\hline \multirow{3}{*}{1} & \multirow{3}{*}{$U-6 Z r$} & $U$ & $94 \%$ & $90,168 \pm 1,636$ & 2,832 \\
\hline & & $\mathrm{Zr}$ & $6 \%$ & $9,177 \pm 1,433$ & 1,744 \\
\hline & & $\mathrm{Nb}$ & - & - & - \\
\hline \multirow{3}{*}{2} & \multirow{3}{*}{ U-6Zr-1Nb } & $U$ & $93 \%$ & $90,317 \pm 2,055$ & 0,628 \\
\hline & & $\mathrm{Zr}$ & $6 \%$ & $9,020 \pm 1,876$ & 1,144 \\
\hline & & $\mathrm{Nb}$ & $1 \%$ & $0,958 \pm 0,024$ & 0,24 \\
\hline \multirow{3}{*}{3} & \multirow{3}{*}{ U-6Zr-4Nb } & $U$ & $90 \%$ & $89,780 \pm 0,537$ & 0,317 \\
\hline & & $\mathrm{Zr}$ & $6 \%$ & $9,562 \pm 0,344$ & 3,218 \\
\hline & & $\mathrm{Nb}$ & $4 \%$ & $4,923 \pm 0,047$ & 0,876 \\
\hline \multirow{3}{*}{4} & \multirow{3}{*}{$\mathrm{U}-6 \mathrm{Zr}-7 \mathrm{Nb}$} & $U$ & $87 \%$ & $83,353 \pm 0,632$ & 3,015 \\
\hline & & $\mathrm{Zr}$ & $6 \%$ & $8,043 \pm 0,698$ & 1,345 \\
\hline & & $\mathrm{Nb}$ & $7 \%$ & $8,057 \pm 0,038$ & 1,019 \\
\hline
\end{tabular}




\section{c. Analisis Kadar Pengotor dengan AAS}

Hasil analisis kadar pengotor menggunakan AAS yang ditampilkan pada Tabel 3 menunjukkan terdapat beberapa unsur yang melebihi ambang batas maksimum yang disyaratkan, antara lain Al, Fe dan Si. Namun, keberadaan unsur-unsur tersebut masih dapat diterima karena tidak cukup untuk membentuk fasa baru baik dengan logam $\mathrm{U}$, logam $\mathrm{Zr}$ maupun $\mathrm{Nb}$. Selain itu, unsur Al, Fe, dan Si mempunyai tampang lintang rendah sehingga dari sisi neutronik tidak mengkhawatirkan. Pengotor dalam bahan bakar nuklir dapat mengganggu operasi di reaktor, terutama apabila unsur pengotor memiliki tampang serapan neutron yang tinggi [10], serta kemungkinan pengaruh ketahanan korosinya apabila ditinjau dari aspek elektrokimia. Unsur yang perlu diperhatikan dari sisi sifat neutronik/ tampang lintang serapan netron mikroskopik adalah unsur B, Cd dan Hf. Ketiga unsur tersebut mempunyai tampang lintang yang cukup besar yakni masing-masing sebesar 3863,7 barn, 2520 barn, 115 barn [11, 12 , 13] dan keberadaan di dalam bahan bakar masing-masing tidak boleh lebih besar dari 4 ,
2, dan 100 ppm [14,13]. Apabila tampang lintang serapan neutron mikroskopik tinggi dikhawatirkan reaktivitas reaktor akan turun dan mengakibatkan reaktor terhenti. Ketiga unsur tersebut tidak dapat terdeteksi melalui pengujian AAS yang ada karena keterbatasan limit deteksi. Peralatan yang digunakan untuk mendeteksi unsur-unsur tersebut adalah Inductively coupled plasma optical emission spectroscopy (ICP-OES) yang mempunyai limit deteksi besar sehingga mampu mendeteksi keberadaan unusur-unsur tersebut. Adanya pengotor bahan bakar nuklir seperti $\mathrm{Al}$, Fe dan $\mathrm{Si}$ dalam bahan bakar nuklir dapat berasal dari bulk material logam sebelum dipadukan, adanya kontaminasi saat proses pembuatan paduan, maupun pada saat proses preparasi analisis destruktif.

Berdasarkan analisis kadar $\mathrm{U}, \mathrm{Zr}$ dan kandungan unsur pengotor, didapatkan bahwa kadar $\mathrm{U}, \mathrm{Zr}$ dan $\mathrm{Nb}$ mendekati yang direncanakan dengan selisih $<5 \%$ serta kandungan unsur pengotor relatif kecil, maka ditinjau dari komposisi kimia, bahan bakar yang diuji masih memenuhi persyaratan sebagai bahan bakar reaktor riset.

Tabel 3. Hasil analisis pengotor paduan U-6Zr-xNb dan batas maksimal yang diijinkan

\begin{tabular}{|c|c|c|c|c|c|}
\hline \multirow[b]{2}{*}{ Unsur } & \multicolumn{5}{|c|}{ Konsentrasi Pengotor dalam Sampel (ppm) } \\
\hline & $U-6 Z r$ & $\mathrm{U}-6 \mathrm{Zr}-1 \mathrm{Nb}$ & $\mathrm{U}-6 \mathrm{Zr}-4 \mathrm{Nb}$ & $\mathrm{U}-6 \mathrm{Zr}-7 \mathrm{Nb}$ & $\begin{array}{c}\text { Batas } \\
\text { maksimum }\end{array}$ \\
\hline $\mathrm{Ag}$ & $<$ LOD 0,00003 & $<$ LOD 0,00003 & $<$ LOD 0,00003 & $<$ LOD 0,00003 & 1 \\
\hline $\mathrm{Al}$ & $298,8093 \pm 0,01$ & $51,7464 \pm 0,001$ & $8,5847 \pm 0,01$ & $943,3685 \pm 0,01$ & 250 \\
\hline $\mathrm{Ca}$ & $2,8084 \pm 0,05$ & $2,5873 \pm 0,04$ & $51,9990 \pm 0,07$ & $14,3779 \pm 0,04$ & 200 \\
\hline $\mathrm{Cr}$ & $87,2838 \pm 0,04$ & $64,6831 \pm 0,04$ & $50,5273 \pm 0,01$ & $109,4484 \pm 0,06$ & 200 \\
\hline $\mathrm{Cu}$ & $24,9382 \pm 0,01$ & $22,3157 \pm 0,02$ & $39,2445 \pm 0,01$ & $38,2923 \pm 0,03$ & 250 \\
\hline $\mathrm{Fe}$ & $110,0876 \pm 0,06$ & $75,5175 \pm 0,09$ & $32,2541 \pm 0,07$ & $250,7336 \pm 0,04$ & 250 \\
\hline $\mathrm{Li}$ & $<$ LOD 0,0001 & $<$ LOD 0,0001 & $<$ LOD 0,0001 & $<\operatorname{LOD} 0,0001$ & - \\
\hline $\mathrm{Mg}$ & $9,5259 \pm 0,03$ & $<$ LOD 0,0002 & $4,3046 \pm 0,05$ & $2,8022 \pm 0,03$ & 200 \\
\hline $\mathrm{Mn}$ & $6,5154 \pm 0,01$ & $3,5576 \pm 0,05$ & $2,4528 \pm 0,06$ & $6,1620 \pm 0,07$ & 250 \\
\hline Mo & $<$ LOD 0,00003 & $<$ LOD 0,00003 & $<$ LOD 0,00003 & $<$ LOD 0,00003 & - \\
\hline $\mathrm{Ni}$ & $189,1710 \pm 0,04$ & $171,5718 \pm 0,04$ & $157,3461 \pm 0,01$ & $163,4390 \pm 0,06$ & 200 \\
\hline $\mathrm{Pb}$ & $<$ LOD 0,0001 & $<\operatorname{LOD} 0,0001$ & $<$ LOD 0,0001 & $<$ LOD 0,0001 & 200 \\
\hline $\mathrm{Si}$ & $1875,9830 \pm 0,03$ & $194,0492 \pm 0,01$ & $<$ LOD 0,0001 & $381,4554 \pm 0,06$ & 60 \\
\hline Sn & $<$ LOD 0,00001 & $<\operatorname{LOD} 0,0001$ & $<\operatorname{LOD} 0,0001$ & $<$ LOD 0,0001 & 50 \\
\hline $\mathrm{Zn}$ & $11,5592 \pm 0,04$ & $13,4702 \pm 0,02$ & $2,1094 \pm 0,01$ & $7,9079 \pm 0,03$ & 250 \\
\hline
\end{tabular}




\section{d. Uji Densitas Paduan U-6Zr-xNb}

Hasil uji densitas paduan U-6Zr-xNb menggunakan autopiknometer ditampilkan pada Tabel 4. Berdasarkan data tersebut, semakin tinggi komposisi $\mathrm{Nb}$, maka kecenderungan densitas sampel akan semakin menurun. Perlu diketahui bahwa unsur $\mathrm{Nb}$ mempunyai densitas lebih rendah daripada unsur $U$ sehingga penambahan unsur $\mathrm{Nb}$ yang semakin besar mengakibakan densitas paduan U-6Zr-xNb semkin menurun. Nilai densitas unsur $\mathrm{U}, \mathrm{Zr}$, dan $\mathrm{Nb}$ masing-masing adalah sebesar $19,1 \mathrm{~g} / \mathrm{mL}$ [15], $6,52 \mathrm{~g} / \mathrm{mL}$ [16] dan $8,57 \mathrm{~g} / \mathrm{mL}$ [17]. Selain dipengaruhi oleh densitas masingmasing komposisi logam yang dipadukan, adanya sampel yang memiliki pori serta pengotor dari logam lain juga dapat mempengaruhi densitas paduan, sehingga densitas sampel secara real nilainya menjadi lebih kecil dibandingkan dengan densitas teoritisnya. Hasil uji densitas selanjutnya digunakan menjadi salah satu parameter dalam menghitung laju korosi paduan $\mathrm{U}-6 \mathrm{Zr}-\mathrm{xNb}$.

Tabel.4. Hasil Uji Densitas Paduan U-6Zr-xNb

\begin{tabular}{lccc}
\hline \multicolumn{1}{c}{ Sampel } & Massa $(\mathrm{g})$ & Volume $(\mathrm{mL})$ & Densitas $(\mathrm{g} / \mathrm{mL})$ \\
\hline Spheremicromerities & 11,6926 & $1,55422 \pm 4,32 \mathrm{e}-4$ & $7,5231 \pm 2,09 \mathrm{e}-3$ \\
U-6Zr & 8,8679 & $0,52226 \pm 8,36 \mathrm{e}-5$ & $16,9798 \pm 2,72 \mathrm{e}-3$ \\
U-6Zr-1Nb & 9,2556 & $0,55718 \pm 4,47 \mathrm{e}-4$ & $16,6115 \pm 1,33 \mathrm{e}-2$ \\
U-6Zr-4Nb & 8,723 & $0,55938 \pm 1,22 \mathrm{e}-4$ & $15,594 \pm 3,41 \mathrm{e}-3$ \\
U-6Zr-7Nb & 7,4887 & $0,48766 \pm 4,14 \mathrm{e}-4$ & $15,3564 \pm 1,36 \mathrm{e}-2$ \\
\hline
\end{tabular}

\section{e. Makrostruktur Paduan U-6Zr-xNb Pasca Uji Korosi}

Pengujian korosi yang dilakukan dalam tiga media yang berbeda yaitu larutan $\mathrm{HNO}_{3}$ dengan $\mathrm{pH} 1,30$; air bebas mineral dengan $\mathrm{pH}$ 8,28; dan larutan $\mathrm{NaOH}$ dengan $\mathrm{pH} 10,96$. Hasil pengamatan makrostruktur ditampilkan pada Gambar 1 hingga 3.

\section{e.1. Hasil Pengamatan Produk Korosi U-6Zr-xNb Dalam Media Larutan $\mathrm{HNO}_{3}$ dengan $\mathrm{pH} 1,30$}

Hasil pengamatan makrostruktur pada sampel yang telah diuji korosi menggunakan mikroskop optik seperti ditampilkan pada Gambar 1 menunjukkan terjadinya jenis korosi uniform attack yang ditandai dengan rusaknya permukaan logam secara merata. Hal ini terjadi karena elemen terkorosi bekerja bersamaan, kemudian area katodik dan anodik secara konstan berpindah tempat dan bergerak di sepanjang permukaan logam [18]. Sampel U-6Zr dan $\mathrm{U}-6 \mathrm{Zr}-1 \mathrm{Nb}$ mengalami kerusakan paling kecil karena hanya terdapat sedikit bercak hitam produk korosi, sedangkan pada sampel U-6Zr-4Nb dan U-6Zr-7Nb terdapat bercak hitam yang tersebar secara merata di permukaan sampel. Bercak hitam di permukaan sampel merupakan hasil oksidasi $\mathrm{U}(\mathrm{IV})$ menjadi $\mathrm{U}(\mathrm{VI})$.

\section{e.2. Hasil Pengamatan Makrostruktur Produk Korosi U-6Zr-xNb Dalam Media Air Bebas Mineral Dengan pH 8,28 \\ Hasil pengamatan makrostruktur} pada sampel U-6Zr-xNb paska uji korosi seperti yang dditampilkan pada Gambar 2 menunjukkan bahwa, sampel U-6Zr-xNb memiliki laju korosi yang lebih tinggi di dalam media air bebas mineral pada $\mathrm{pH} 8,28$ dibandingkan dengan media lain. Hasil pengamatan makrostrutur menggunakan mikroskop optik pada keempat sampel terdapat bercak berwarna hitam di permukaan sampel yang merupakan hasil oksidasi dari U (IV) menjadi U (VI). Sampel U-6Zr memiliki area teroksidasi paling besar, dan seiring bertambahnya persentase $\mathrm{Nb}$ 
dalam paduan, area teroksidasi semakin kecil. Hal ini disebabkan adanya $\mathrm{Nb}$ yang membentuk lapisan $\mathrm{Nb}_{2} \mathrm{O}_{5}$ dan bersifat protektif pada permukaan sampel [19].
Sampel U-6Zr mengalami korosi pitting yang ditunjukkan adanya lubang cukup dalam pada area teroksidasi.



(a)

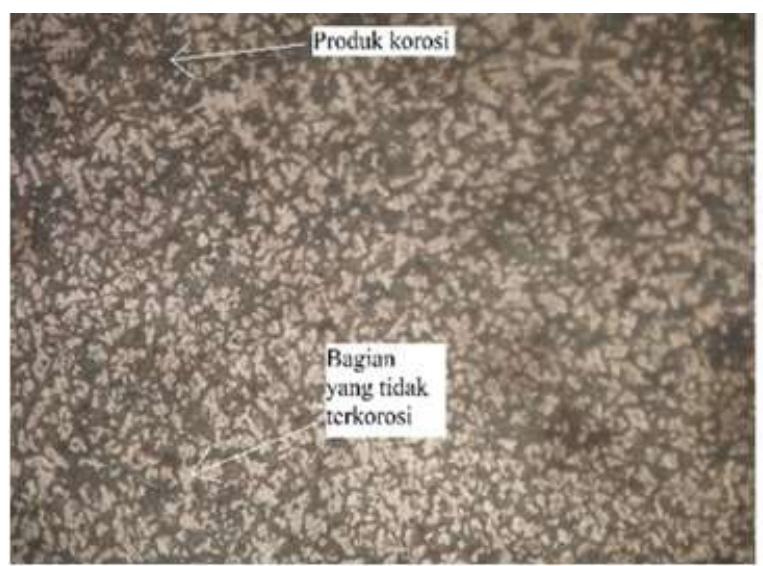

$\overline{50 \mu \mathrm{m}}$

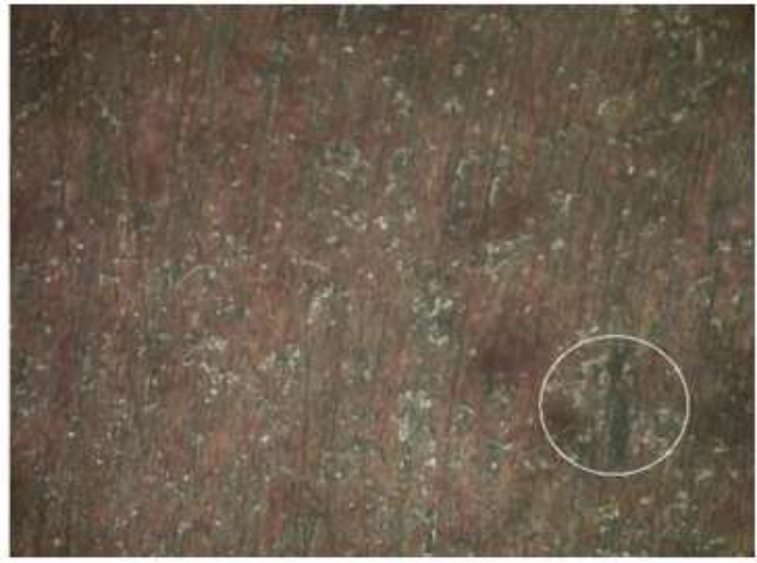

$\overline{50 \mu \mathrm{m}}$

(b)

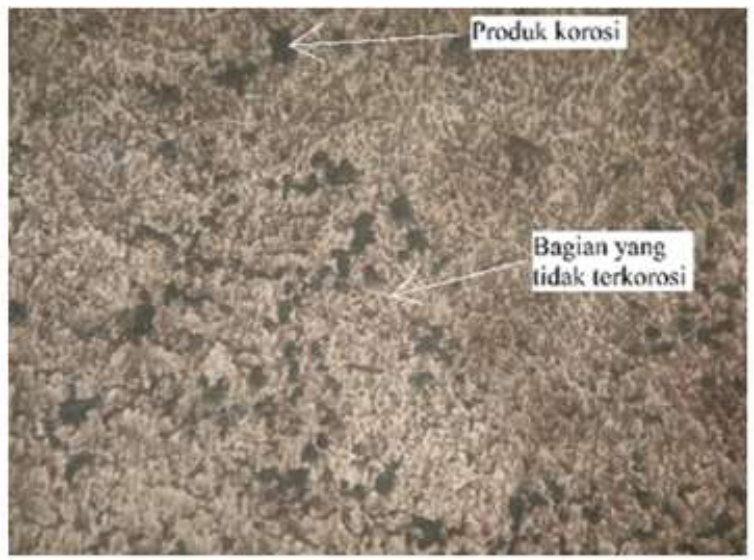

$\overline{50 \mu \mathrm{m}}$

(d)

Gambar 1. Hasil pengamatan makrostruktur menggunakan mikroskop optik hasil uji korosi dalam media larutan $\mathrm{HNO}_{3}$ dengan $\mathrm{pH} 1,30$ untuk paduan:
(a) $U-6 Z r$
(b) $U-6 Z r-1 \mathrm{Nb}$
(c) $U-6 Z r-4 \mathrm{Nb}$
(d) $U-6 Z r-7 \mathrm{Nb}$ 


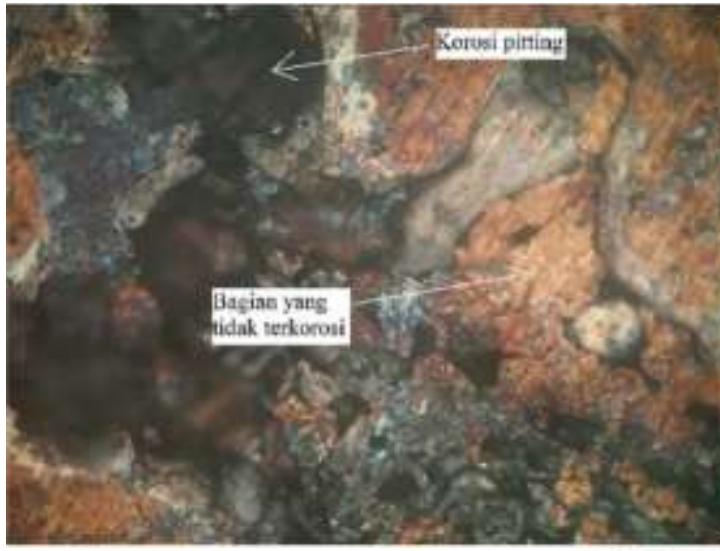

$\overline{50 \mu \mathrm{m}}$

(a)

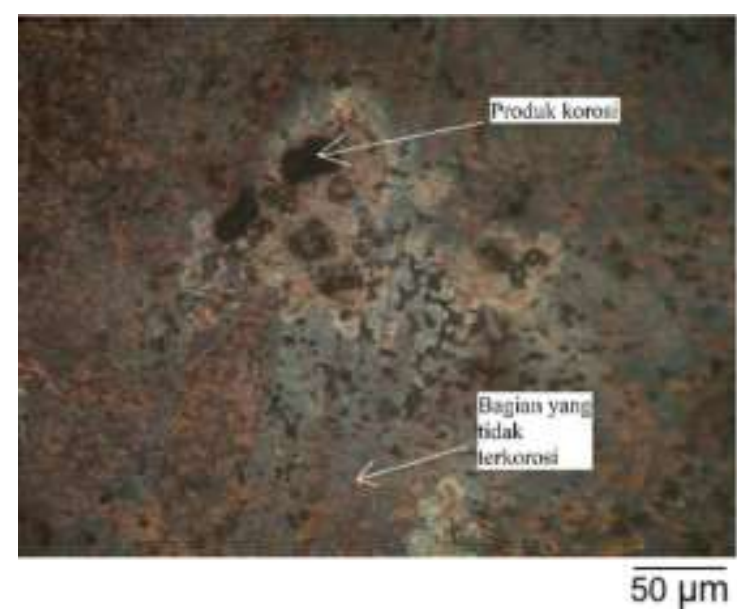

(c)

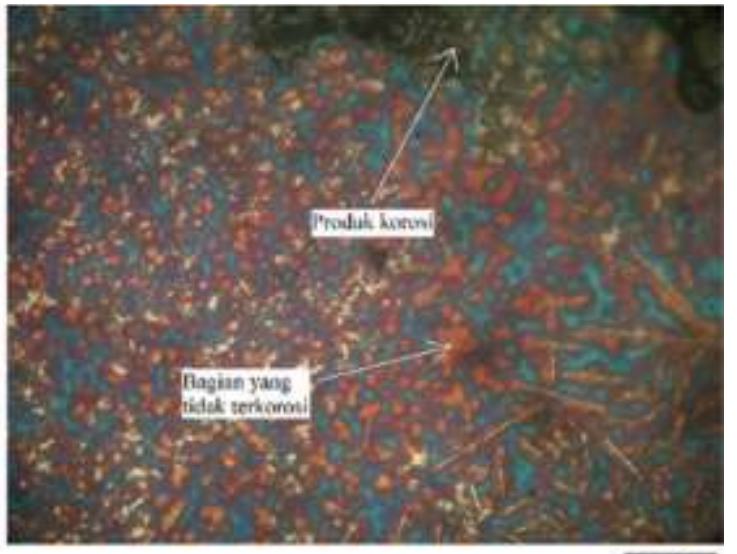

$\overline{50 \mu \mathrm{m}}$

(b)



(d)

Gambar 2. Hasil Pengamatan makrostruktur menggunakan mikroskop optik hasil uji korosi dalam media air bebas mineral dengan $\mathrm{pH} 8,28$ untuk paduan:
(a) $\mathrm{U}-6 \mathrm{Zr}$
(b) $U-6 Z r-1 \mathrm{Nb}$
(c) $U-6 Z r-4 \mathrm{Nb}$
(d) $\mathrm{U}-6 \mathrm{Zr}-7 \mathrm{Nb}$

\section{e.3. Hasil Pengamatan Makrostruktur Produk Korosi U-6Zr-xNb Dalam Larutan $\mathrm{NaOH}$ dengan $\mathrm{pH} 10,96$}

Hasil Pengamatan sampel U-6ZrxNb pada media larutan $\mathrm{NaOH}$ pH 10,96 yang ditunjukkan pada Gambar 3 menunjukkan bahwa jenis korosi yang terjadi adalah uniform attack. Bercak hitam hasil oksidasi $U$ (IV) menjadi $U$ (VI) memiliki ukuran yang seragam dan tersebar merata. Hasil penelitian Petrukin et al, menunjukkan bahwa terbentuk koloid hitam yang diduga merupakan campuran dari $\mathrm{U}(\mathrm{IV})$ dan $\mathrm{U}(\mathrm{VI})$, dimana koloid tersebut sebagian besar adalah $\mathrm{U}(\mathrm{VI})$. Penelitian mengenai pembentukan $\mathrm{U}(\mathrm{IV})$ dan $\mathrm{U}(\mathrm{VI})$ pada bercak hitam tersebut hanya dilakukan pada larutan dengan $\mathrm{pH}$ lebih besar dari 8 [20]. Berdasarkan uji korosi, sampel U-6Zr-xNb memiliki laju korosi yang rendah dalam media larutan $\mathrm{NaOH}$ dengan $\mathrm{pH}$ 10,96 sehingga kerusakan yang terjadi di permukaan sampel tidak terlalu terlihat. 




$\overline{50 \mu \mathrm{m}}$

(a)

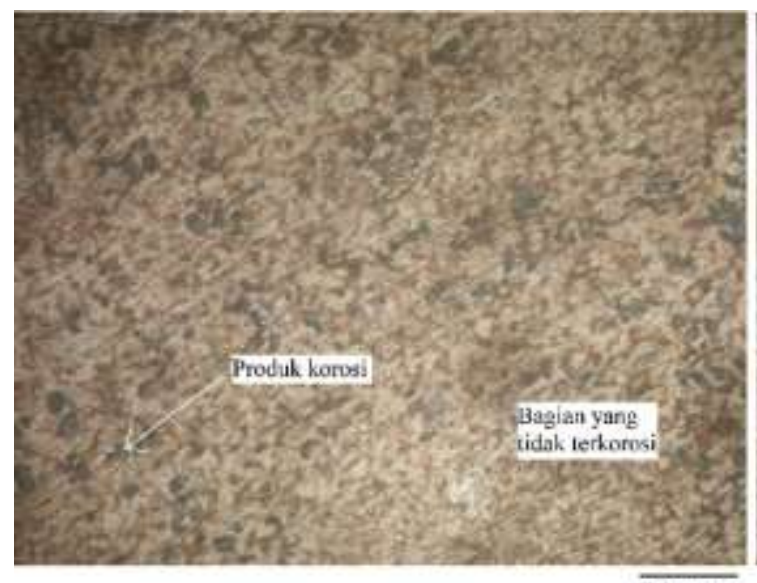

(c)

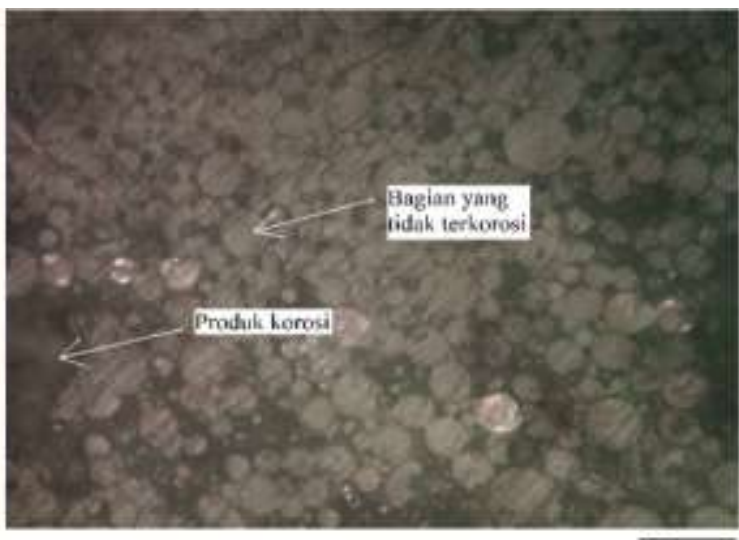

$\overline{50 \mu \mathrm{m}}$

(b)

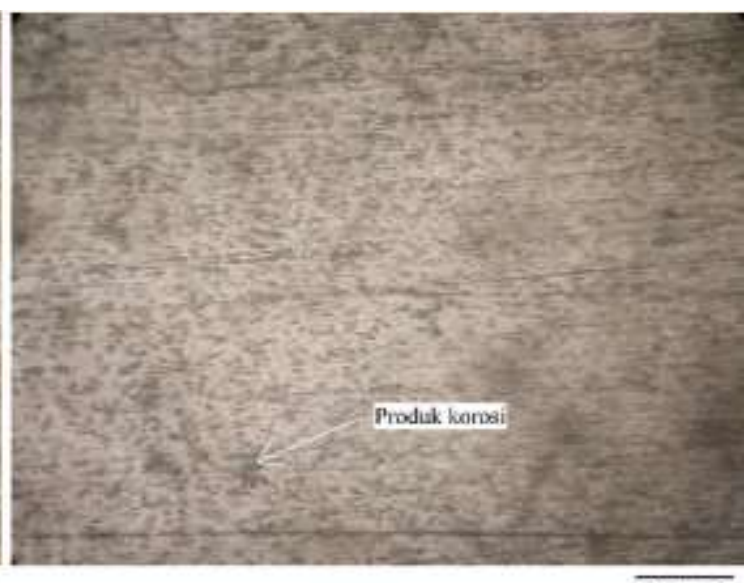

(d)

Gambar 3. Hasil pengamatan makrostruktur menggunakan mikroskop optik hasil uji korosi dalam media larutan $\mathrm{NaOH}$ pH 10,96 untuk paduan:
(a) $U-6 Z r$
(b) $U-6 Z r-1 \mathrm{Nb}$
(c) $\quad \mathrm{U}-6 \mathrm{Zr}-4 \mathrm{Nb}$
(d) $\quad \mathrm{U}-6 \mathrm{Zr}-7 \mathrm{Nb}$

\section{f. Analisis Pembentukan Fasa Paduan U-6Zr-xN Pasca Uji Korosi}

Hasil pengujian dengan menggunakan XRD ditampilkan dalam bentuk pola difraksi U-6Zr-xNb seperti pada Gambar 5.

Karakterisasi paduan U-6Zr-xNb telah dilakukan menggunakan $X$-Ray Diffraction (XRD) pasca perlakuan korosi untuk mengamati fasa yang terbentuk pada paduan. Adanya $\mathrm{Nb}$ pada paduan $\mathrm{U}-\mathrm{Zr}-\mathrm{Nb}$ akan membentuk lapisan protektif selain fasa $\mathrm{yU}][21]$. Pengujian menggunakan XRD, diharapkan muncul peak yang menandakan adanya lapisan $\mathrm{Nb}_{2} \mathrm{O}_{5}$.

Paduan U-6Zr dan U-6Zr-1Nb menunjukkan pola fasa $\alpha-U$ sesuai dengan database JCPDS 98-004-3419, sedangkan paduan U-6Zr-4Nb dan U-6Zr-7Nb menunjukkan pola difraksi fasa $\mathrm{yU}$ sesuai dengan database JCPDS 96-900-8557. Penambahan unsur $\mathrm{Nb}$ dengan presentase kecil tidak terlalu mempengaruhi pembentukan fasa U-y [22],[8]. Paduan uranium yang mengandung presentase penstabil fasa y cukup tinggi akan lebih tahan 
terhadap korosi [8]. Berdasarkan pengamatan pola difraksi, dapat diperkirakan bahwa sampel U-6Zr-4Nb dan U-6Zr-7Nb memiliki ketahanan korosi yang baik karena pola difraksinya menunjukkan bahwa sampel tersebut memiliki fasa U-y. Berdasarkan pola difraksi yang terlihat, tidak ditemukan peak untuk oksida $\mathrm{Nb}_{2} \mathrm{O}_{5}$ sebagai lapisan protektif yang terbentuk selama terjadi korosi. Hal ini disebabkan jumlah lapisan protektif $\mathrm{Nb}_{2} \mathrm{O}_{5}$ yang terbentuk terlalu kecil sehingga tidak terdeteksi oleh XRD.

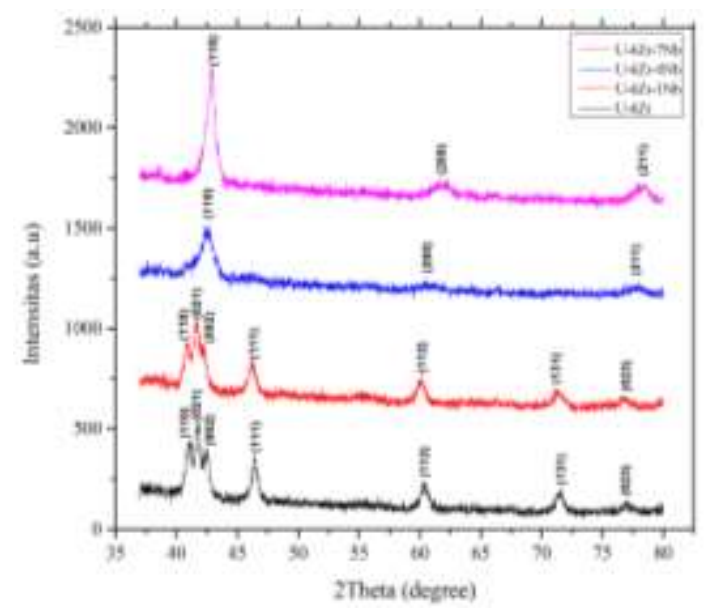

Gambar 1. Pola difraksi paduan U-6Zr-xNb pasca uji korosi.

\section{SIMPULAN}

Dari hasil penelitian dapat disimpulkan bahwa, komposisi kimia paduan U-6Zr-xNb hampir mendekati persentase yang diharapkan. Beberapa unsur pengotor yang melebihi ambang batas antara lain $\mathrm{Al}$, Fe, dan Si. Hasil pengujian densitas menunjukkan bahwa semakin tinggi presentase berat $\mathrm{Nb}$, maka densitas semakin menurun. Pengamatan makrostruktur menunjukkan bahwa produk korosi paling besar terdapat pada media air bebas mineral dengan $\mathrm{pH}$ 8,28. Pengamatan pola difraksi dari pengujian XRD menunjukkan bahwa sampel U-6Zr dan U-6Zr-1Nb membentuk fasa U- $\alpha$, sedangkan sampel U-6Zr-4Nb dan U-6Zr-7Nb membentuk fasa U-y. Lapisan protektif $\mathrm{Nb2O5}$ tidak nampak pada pola difraksi.

\section{UCAPAN TERIMA KASIH}

Penulis mengucapkan banyak terima kasih kepada Kelompok Kendali Kualitas Bidang Fabrikasi Bahan Bakar Nuklir (BFBBN) dan Kelompok Metalografi dan Korosi Bidang Uji Radiometalurgi (BUR) Pusat Teknologi Bahan Bakar Nuklir (PTBBN) yang telah membantu selama proses penelitian. Ucapan terima kasih khususnya kepada bapak Yatno D.A yang telah membantu menyiapkan ingot U-6Zr-xNb, bapak Slamet Pribadi, dan bapak Setia Permana yang telah membantu menyiapkan sampel untuk uji korosi.

\section{PERNYATAAN KONTRIBUTOR}

Sebagai kontributor utama adalah Masrukan dan Deninta Andara Perdana, Deni Mustika dan Jumaeri sebagai kontributor anggota.

\section{DAFTAR PUSTAKA}

[1]. S. Banerjee and T. R. Govindan Kutty, "Nuclear fuels," in Functional materials, first edition, Elsevier Inc., 2012, pp. 387-466.

[2]. Supardjo," Pengembangan paduan uranium berbasis UMo sebagai kandidat bahan bakar nuklir untuk reaktor riset menggantikan bahan bakar dispersi $\mathrm{U}_{3} \mathrm{SI}_{2}$-Al", Prosiding Seminar Nasional Pengembangan Energi Nuklir IV, 2011 Pusat Pengembangan Energi Nuklir, Badan Tenaga Nuklir Nasional, hal. 443-451.

[3]. Masrukan, T. Yulianto, da Sungkono, "Pengaruh unsur Nb pada bahan bakar paduan UZrNb terhadap densitas, kekerasan dan mikrostruktur," Jurnal IImiah Daur Bahan Bakar Nuklir Urania, vol. 16, no. 3, pp. 115-121, 2010.

[4]. J. Lisboa, et.al, "Engineering of fuel plates on uranium-molybdenum monolithic: Critical issues," World J. Nucl. Sci. Technol., vol. 5, no. 4, pp. 274-286, 2015. 
[5]. A. Banos, N. J. Harker, and T. B. Scott, "A review of uranium corrosion by hydrogen and the formation of uranium hydride," Corros. Sci., vol. 136, pp. 129-147, 2018.

[6]. R. Li and X. Wang, "Effect of niobium additions on initial hydriding kinetics of uranium," Journal of Nuclear Material., vol. 449, no. 1-3, pp. 49-53, 2014,

[7]. L. L. Snead, D. T. Hoelzer, M. Rieth, and A. A. N. Nemith, "Refractory alloys:vanadium, niobium, molybdenum ,tungsten," in Structural Alloys for Nuclear Energy Applications, pp. 585640, 2019.

[8]. S. Kaity, J. Banerjee, S. C. Parida, and V. Bhasin, "Structural, microstructural and thermal analysis of $\mathrm{U}-(6-\mathrm{x}) \mathrm{Zr}-\mathrm{xNb}$ Alloys $(x=0,2,4,6)$," Journal of Nuclear Material., vol. 504, pp. 234-250, 2018.

[9]. S. B. Lyon, "Corrosion of uranium and its alloys," Shreir's Corros., vol. 1, pp. 2181-2191, 2010.

[10]. Masrukan, T. Yulianto, and A. Muchsin, "Komparasi hasil analisis komposisi kimia di dalam paduan $\mathrm{U}$-Zr-Nb dengan menggunakan teknik XRF dan AAS," Jurnal IImiah Daur Bahan Bakar Nuklir Urania, vol. 17, no. 3, pp. 152-159, 2011.

[11]. J. R. Lamarsh, and A. J. Baratta, "Introduction to nuclear engineering, 3 th edition," Prentice Hall, Inc., New Jersey, 2001.

[12]. Masrukan, M H. Alhasa, Yanlinastuti, "Korelasi komposisi unsur terhadap sifat termal serbuk bahan bakar U$\mathrm{ZrH}_{\mathrm{x}}{ }^{\prime}$, Jurnal IImiah Daur Bahan Bakar Nuklir Urania, vol. 22, no. 2, pp. $65-132,2016$.

[13]. N. Aziz, N. A. Kundari, D. Biyantoro, "Pemisahan zirkonium dan hafnium dengan metode sir (Solvent
Impregnated Resins)", Jurnal Forum Nuklir, vol. 11, no. 1, 2017.

[14]. Anonim," Sertifikat uji elemen bakar dan elemen kendali bahan bakar $\mathrm{U}_{3} \mathrm{Si}_{2}$-Al", PT Inuki (Persero), INI -01F01-060, Revisi 0, 2020.

[15]. L. S. Keith, O. M. Faroon, and B. A. Fowler, "Uranium," in Handbook on the Toxicology of metals: Fourth edition, vol. 1, Elsevier, pp. 1307-1345, 2015.

[16]. R. B. Adamson and P. Rudling, "Properties of zirconium alloys and their applications in light water reactors (LWRs)", Woodhead Publishing Limited, 2013.

[17]. C. Nico, T. Monteiro, and M. P. F. Graça, "Progress in materials science niobium oxides and niobates physical properties: Review and prospects," $J$. Prog. Mater. Sci., vol. 80, pp. 1-37, 2016.

[18]. J. Riskin, and A. Khentov, "Corrosion basics, electrocorrosion and protection of metals, Elsevier Inc., 2019.

[19]. Y. Wu, et al. "Effect of niobium element on the electrochemical corrosion behavior of depleted uranium", Journal of Nuclear Materials, vol. 478, pp.7-12, 2016.

[20]. V. F. Peretrukhin, et.al., "Corrosion of uranium and its low content $\mathrm{Zr}$, $\mathrm{Nb}$, and $\mathrm{Ru}$ alloys in aqueous solutions", Protection of Metals, vol. 44, no. 3, pp. 211-232, 2008.

[21]. Y. Wu et al., "Effect of niobium element on the electrochemical corrosion behavior of depleted uranium," Journal of Nuclear Material, vol. 478, pp. 7-12, 2016.

[22]. K. Ghoshal, S. Kaity, S. Mishra, and A. Kumar, "Microstructural investi gation of uranium rich $\mathrm{U}-\mathrm{Zr}-\mathrm{Nb}$ ternary alloy system," Journal of Nuclear Material, vol. 446, no. 1-3, pp. 217-223, 2014. 